\title{
Literature and insights Editorial
}

\section{Looking forward to the past}

Caspar Henderson, to quote the blurb inside a certain book I shall name momentarily, is "a Writer and Journalist whose work has appeared in the Financial Times, the Independent and New Scientist". I think that is worth mentioning because someone who has an effective reach into a range of disciplines that these publications represent and a mind to enquire in a variety of areas ought to be the kind of person the $A A A J$ would see as a potential reader. Even if not, that quality of being inquisitive is to be encouraged among those readers we have.

About animals, Henderson said, we are always fascinated in "the ways they never stop being strange or surprising" and that such attributes "feature constantly among the most shared articles and video clips on the web". Bear with me here while I follow his train of thought as I think it relates directly to some of the better characteristics of academic enquiry in accounting, and those stem from curiosity and compassion. Henderson goes on to say:

The following seems to be true; our attention is often momentary or disorganized, but fascination with other ways of being, including that of animals, is seldom far from our minds, and gushes up like spring water from within dark rock in every human culture. We may be shameless voyeurs, passionate conservationists or simply curious, but we are seldom indifferent. Like our ancestors, we are continually asking ourselves, consciously or unconsciously, "what has this got to do with me, my physical existence, the things I hope for and the things I fear?" (p. XIII).

I home in on phrases like "other ways of being", "curious" and "seldom indifferent" as these are quite pertinent. The clincher is in the tail of the quote above, with the questions about relating what we see to an understanding of our individual existence and the interrelationship of this to our hopes and fears. It sounds like the stuff of a creative writing class and with good reason. Any good teacher of creative writer tries to instil in his or her students an awareness of character motivation: what makes them tick; what drives them; and what do they hope for and fear? It is because it relates to what we typically call "the human condition".

I have always felt that the best aspects of disciplinary enquiry are those that see connections beyond their silos, and that stretch towards other areas of thinking. The constructs that we deal with are convenient but they remain merely convenient divisions in many cases. It would take a fool to say that the $A A A J$ ought now to step into zoology or archaeology, would not it? Or is that a matter of particular interests in each case simply working more effectively in isolation? What is possible? What bridging between different areas of academic enquiry offers possible benefits? At the least, it suggests that we ought to keep an open mind regarding such things. The $A A A J$ deals with many subjects but it may not surprise you that I find it most satisfying personally when it ventures into new areas,

Accounting, Auditing \& Accountability Journal (AAAJ) welcomes submissions of both research papers and creative writing. Creative writing in the form of poetry and short prose pieces is edited for the literature and insights section only and does not undergo the refereeing procedures required for all research papers published in the main body of $A A A J$. Author guidelines for contributions to this section of the journal can be found at: www.emeraldgrouppublishing.com/products/journals/author guidelines.htm?id=aaaj

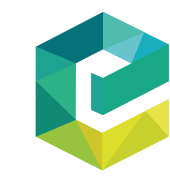

Accounting, Auditing \& Accountability Journal Vol. 30 No. 1, 2017 pp. $217-218$ DOI 10.1108/AAAJ-11-2016-2782 
ones where the nature of enquiry is both original and informed by that quest to better understand who we are. It is, as some people say, a "big ask", but one worth undertaking.

The contributors of creative material for this issue are John E. Karayan and Ashley Burrowes. They conjecture over the competing influences of quantitative and qualitative data in financial reporting, a seemingly dry argument that actually has a direct bearing on how we think. Indirectly then, we come to the notion of modes of thinking and their utility again. I wonder what sort of conversation there might be between Caspar Henderson and the composers of the featured poem on that score.

Your own creative contributions can be submitted via ScholarOne (see below), and your email correspondence is always welcome, of course, at: steve.evans@flinders.edu.au.

Steve Evans

Literary Editor

\section{Further reading}

Henderson, C. (2012), The Book of Barely Imagined Beings: A 21st Century Bestiary, Granta Publications, London. 